\title{
A iconografia das estelas funerárias dos Círculos Tumulares A e B de Micenas
}

\author{
ANA CLAUDIA TORRALVO \\ Doutoranda do Departamento de Antropologia \\ Faculdade de Filosofia, Letras e Ciências Humanas \\ Universidade de São Paulo
}

\begin{abstract}
RESUMO: Este artigo está dividido em duas partes: a primeira é composta por um catálogo das estelas funerárias com relevos provenientes dos Círculos Tumulares A e B de Micenas. A segunda é composta por uma análise na qual foram consideradas as opiniões anteriores à descoberta do Círculo Tumular B (de quando datam os dois únicos estudos dedicados exclusivamente ao entendimento das imagens contidas nesses relevos). A essas opiniões contraponho uma posição mais recente que entende tais imagens como representações simbólicas ligadas a um estágio evolutivo determinado da civilização micênica a qual, nesse momento, passa por um processo de consolidação de elites e estabelecimento de relações de poder mais duradouras: o germe da sociedade palacial micênica.
\end{abstract}

PALAVRAS-CHAVE: Círculos Tumulares, estelas, Micenas, poder, simbologia, sociedade.

Os Círculos Tumulares A e B de Micenas (Argólida - SE do Peloponeso - figura nº 1) são formados por um conjunto de túmulos de arquitetura particularmente diferenciada ${ }^{1}$ encontrado apenas em Micenas: os túmulos em poço, datados de c. 1650-1550 a.C.. O Círculo Tumular B, cronologicamente anterior ao Círculo Tumular A foi escavado por G. E. Mylonas e I. Papadimitriou na década de 50, sendo constituído de 26 túmulos. Sobre esses túmulos foram descobertos diversos fragmentos de estelas ${ }^{2}$, embora somente duas fossem esculpidas: uma proveniente do Túmulo A e outra proveniente do túmulo $\Gamma^{3}$. Esta última apresenta uma lacuna na região central resultante de sua utilização posterior como base para outra estela. O Círculo Tumular A, escavado em 1876 por H. Schliemann e S. Stamatakis, revelou seis túmulos (figura $n^{\circ} 2$ ). Três estelas esculpidas são provenientes do túmulo $\mathrm{V}$, uma do túmulo II e outra ainda, cuja proveniência não é claramente estabelecida; o restante do material é constituído por oito conjuntos de fragmentos agrupados e numerados por W. A. Heurtley (Heurtley, 1921-3) ${ }^{4}$.

Estas estelas são lajes de calcário trabalhadas em um tipo de baixo relevo muito rústico e primitivo, ao menos no que diz respeito às imagens figurativas, sendo que as representações geométricas são melhor trabalhadas. Quanto às suas dimensões a altura está por volta de $1,50 \mathrm{~m}$ mas nenhuma dessas foi encontrada intacta. Somente uma, aparentemente completa, apresenta $1,85 \mathrm{~m}$ de altura. 
Para o Círculo Tumular B temos as estelas A e $\Gamma$. A estela A ( $\mathrm{n}^{\circ}$ de registro 490 ) foi encontrada em péssimo estado de conservação e a imagem gravada é quase imperceptível. A cena que pode ser percebida mostra um touro sendo atacado por dois leões; mais à direita está uma figura humana que, por sua vez, ataca um dos leões com uma lança. A estela $G$ ( $\mathrm{n}^{\circ}$ de registro 491), apesar de apresentar nitidamente seus relevos, não possui a região central, perfurada para que pudesse ser reutilizada como base para outra estela. Podemos perceber que o campo é dividido em duas regiões ou registros. No superior foram esculpidas espirais concatenadas; no inferior é representada uma cena, reconstituída por S. Marinatos (Marinatos, 1968, p. 177) (figura $\mathbf{n}^{\circ}$ 3). Nela um touro é atacado por dois leões; à esquerda está uma figura humana aparentemente ferida ou possivelmente morta; à direita outra figura humana armada avança na direção das feras; dois outros elementos geométricos aparecem do lado esquerdo da cena.

A estela 1 ( $\mathrm{n}^{\circ}$ de registro 1427), do Círculo Tumular A, foi encontrada sobre o túmulo $\mathrm{V}$, faltando-lhe a parte superior (figura $n^{\circ} 4$ ). Uma moldura de volutas enquadra um registro que apresenta duas cenas: na parte superior uma figura humana portando uma espada conduz um carro puxado por cavalos a galope, da esquerda para a direita; sob as patas dos cavalos outra figura humana está caída sob um escudo em forma de 8. Na parte inferior, um leão persegue outro animal de difícil identificação ${ }^{5}$.

A estela 2 ( $\mathrm{n}^{\circ}$ de registro 1430 ) foi encontrada sobre o túmulo II do Círculo Tumular A, também faltando-lhe a parte superior. Sua superfície é dividida em três painéis verticais, sendo o central liso. Nos outros dois painéis foi esculpido um motivo de meandros (figura $\mathrm{n}^{\circ} 5$ ).

A estela $3\left(\mathrm{n}^{\circ}\right.$ de registro 1434$)$ é composta de fragmentos de borda. Neles está esculpido um motivo de espirais concatenadas em conjunto com pequenos círculos (figura $n^{\circ} 6$ ).

A estela $4\left(\mathrm{n}^{\circ}\right.$ de registro 1429) muito possivelmente apresenta sua altura original, medindo $1,85 \mathrm{~m}$ de altura, tendo sido também encontrada sobre o túmulo $\mathrm{V}$ (figura $\mathrm{n}^{\circ} 4$ ). A superfície foi dividida em três registros horizontais. No superior foi esculpido um motivo de espirais concatenadas e no inferior dois círculos interligados e decorados com volutas muito semelhantes a outros encontrados em selos egípcios e em botões de ouro do túmulo III do próprio Círculo Tumular A (Heurtley, 1921-3, p. 138 e ss.). No registro central foi gravada uma cena onde um homem está sobre um carro puxado por cavalos, possivelmente dois, a galope, da esquerda para a direita. À suą frente outra figura humana, brandindo um objeto, volta-se na direção do carro. Um objeto projeta-se da parte posterior do veículo, que, apesar da imprecisão do relevo, parece ser uma espada ou adaga.

A estela $5\left(\mathrm{n}^{\circ}\right.$ de registro 1428$)$ também foi encontrada sobre o túmulo V. Apresenta dois registros horizontais sendo o superior composto por espirais concatenadas. No inferior, um carro é puxado por um cavalo a galope da esquerda para a direita; no carro, o condutor segura as rédeas com a mão direita e uma espada com a esquerda. À frente do carro, do lado direito da cena, outra figura humana de pé está brandindo um objeto, possivelmente uma faca. Suas pernas estão levemente arqueadas, embora não pareça mover-se; está voltada para a direita, de costas para o carro. Sob as patas do cavalo e os pés da figura humana foi esculpido um motivo de volutas. Acima do cavalo foi colocada uma versão do "símbolo do papiro canópico" e do lado esquerdo

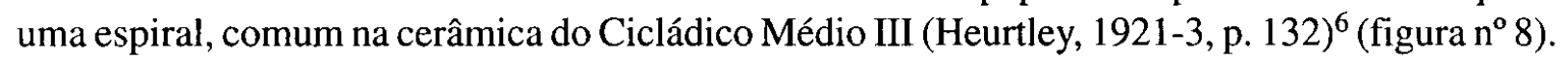

A estela $6\left(\mathrm{n}^{\circ}\right.$ de registro 1431$)$ não tem origem definida e é constituída de três fragmentos (figura $n^{\circ} 9$ ). Num registro horizontal superior foram encontradas espirais concatenadas, mas o fragmento está em péssimo estado. O restante do espaço foi dividido em três painéis verticais sendo que os externos são preenchidos com espirais concatenadas e, do lado direito, no interior de uma espiral, foi gravada uma roseta muito semelhante tematicamente aos círculos inferiores da estela 4. O painel central apresenta a figura de três cavalos com as patas dianteiras alçadas.

O número 7 designa um conjunto de fragmentos dos quais $b$ e $c$ são fragmentos de borda com espirais concatenadas (figura $\mathrm{n}^{\circ} 10$ ). $\mathrm{O}$ fragmento $a$ representa parte de um registro inferior 
onde aparece a parte dianteira de um cavalo e pode ser semelhante à estela 6 , já que não são perceptíveis sinais de rédeas no animal. O número 8 (figura $n^{\circ} 11$ ) também representa um conjunto de fragmentos sendo que $b, c$ e $d$ apresentam a mesma borda em meandros que $a$. O fragmento maior, $8 a$, mostra parte da borda esquerda separada do registro central e do superior. Neste último aparece uma roda e sob ela a ponta de uma lança. No outro registro aparecem as cabeças de duas figuras humanas. O número 9 (figura $\mathrm{n}^{\circ} 12$ ) é composto por dois fragmentos. Em $9 a$ uma figura humana está de pé enquanto outra está tombada, embora dessa só apareçam as pernas. Em $9 b$ estão gravadas duas rodas, parte de um carro e a pata traseira de um cavalo, bem como as rédeas; acima destas, as pernas de outra figura humana de pé e ainda outra caída.

Em $10 a$ vemos uma figura humana com joelhos flexionados e segurando um objeto com a mão direita. $10 b$ possui apenas a representação de um par de pernas. Esse conjunto de fragmentos foi encontrado sobre o túmulo VI, o mais antigo do Círculo Tumular A. O trabalho nesta estela foi mais de incisão que de entalhe em baixo relevo, como também acontece na estela $\mathrm{A}$ do Círculo Tumular B. Os dois fragmentos que compõem o conjunto de número 11 (figura $\mathrm{n}^{\circ} 14$ ) são muito semelhantes quanto ao estilo ao conjunto 10 (figura $\mathrm{n}^{\circ} 13$ ). $11 a$ mostra a parte superior de um cavalo, suas rédeas e uma lança. $11 b$ mostra a cabeça e o braço de uma figura humana segurando um objeto semelhante ao observado em $10 a$. O número 12 é um conjunto de fragmentos que, embora não representem uma mesma estela, apresentam o mesmo estilo e são todos de calcário conglomerado (de $a$ a $k$ - figura $\mathrm{n}^{\circ} 15$ ).

W. A. Heurtley (Heurtley, 1921-3, p. 138 e ss.) dividiu as estelas em três classes segundo a técnica e o material. À Classe I pertencem os conjuntos de fragmentos $10 \mathrm{e} 11$ devido à utilização de incisões no lugar de baixos relevos e ambos são trabalhados em tufo, tipo de calcário macio. A esta classe deve também pertencer a estela A do Círculo Tumular B pois sua técnica de incisões é muito semelhante à utilizada nos fragmentos $10 \mathrm{e} 11^{7}$.

$\mathrm{Na}$ Classe II, além de o material utilizado ser o conglomerado, todas têm como principal característica a divisão da área em registros e a ela pertencem todas as outras estelas e conjuntos de fragmentos, com exceção da estela 1. Quanto à técnica e ao estilo, formam um todo homogêneo, o que pode ser percebido através do padrão de espirais concatenadas presentes em $3,4,5$, 6 e 7. A esta classe também pertence a estela $\Gamma$ do Círculo Tumular $B$, a partir da sintaxe da imagem pois, apesar de seu estado, fica claro que o registro superior apresenta espirais concatenadas e o inferior, uma cena figurativa. W. A. Heurtley determina três características comuns a todas as estelas: 1) o tratamento geométrico dos motivos espirais, meandros e rosetas, os quais não aparecem pela primeira vez nas estelas, já estando presentes em diversos objetos do mobiliário dos túmulos do Círculo Tumular $\mathrm{A}^{8}$ e na estela $\Gamma$; 2 ) Divisão em registros através de linhas ou faixas lisas. Essa divisão em registros tem sua origem na cerâmica de estilo Matt-Painted continental do final do Heládico Médio, na qual há uma permanência da tradição geométrica (Heurtley, 1921-3, p. 142 e nota 11, jarro do túmulo VI); 3) As figuras humanas são desenhadas geometricamente, sendo o movimento da ação sempre da esquerda para a direita.

A Classe III é formada apenas pela estela 1. A geometria de suas espirais é mais ambiciosa e naturalista. Abandonou-se aí a divisão em registros e a cena apresenta duas ações diferentes: a do carro e a da perseguição.

Após a organização e catalogação das estelas, W.A. Heurtley conclui pela permanência de padrões geométricos meso-heládicos herdados da cerâmica e a inovação da decoração figurativa; coloca a estela 1 , da Classe III, como o marco do rompimento definitivo com a tradição geométrica (Heurtley, 1921-3, p. 148). Contudo, esse autor não levou em consideração, quando elaborou seu esquema dedutivo, o próprio mobiliário dos túmulos abaixo das estelas. São vários 
os exemplos de que já havia representações figurativas como as adagas em marchetaria de metal. Parece que se chegou num acordo quanto ao fato de estas estelas terem sido gravadas por artesãos não habituados ao trabalho em pedra, mas sim ao trabalho em metal (Vermeule, 1975, p. 16).

Apesar do pioneirismo de W. A. Heurtley e da solução satisfatória que deu à questão dos motivos em espirais e meandros, as cenas figurativas ainda causam uma grande controvérsia. É visível a qualquer observador que nas cenas representadas, ao menos aquelas que chegaram integralmente até nós, sempre está presente o carro. Dentre os fragmentos, três conjuntos $(8,9 \mathrm{e}$ 11) também apresentam partes de carro, isso para as estelas do Círculo Tumular A. Ambas do Círculo Tumular B mostram leões atacando uma presa, no caso um touro, e homens atacando, ao mesmo tempo, os leões. Podemos então delinear dois esquemas iconográficos distintos: o carro em ação e cenas de ataque, sendo que na estela 1 ambos os esquemas estão presentes, já que nela figuram tanto um carro em ação como um leão atacando uma presa.

G. E. Mylonas foi o primeiro a tentar interpretar essas representações (Mylonas, 1951, p. 134-147), tendo ainda como referencial apenas as estelas do Círculo Tumular A, ou seja, as de números 1, 4 e 5, aquelas que apresentam cenas completas. Sua opinião diferia daquela de $\mathrm{H}$. Schliemann e de A. Evans (Evans, 1929, nota 11), os quais acreditavam que tais cenas representavam batalhas, atitudes ofensivas ou possivelmente a narrativa da morte do indivíduo deposto no túmulo. Tendo usado como referência as imagens incisas sobre os selos e anéis de sinete encontrados nos próprios túmulos do Círculo Tumular A, conclui por estas cenas representarem corridas de carros em jogos fúnebres em honra do morto e não cenas de guerra ou caça (Mylonas, 1951, p. 147, nota 15), tendo como principal argumento o fato de as figuras não portarem elmo e de sempre haver apenas um homem sobre o carro. Nos exemplos da glíptica sempre aparecem dois indivíduos sobre o carro: um o conduz enquanto outro utiliza uma arma, seja a lança ou o arco. Em outras cenas, já de batalha corporal, as figuras portam sempre o elmo e o escudo (figura $\mathrm{n}^{\circ} 17$ ). A ausência de elementos defensivos e o fato de o indivíduo estar sozinho no carro levaram G. E. Mylonas a preferir a interpretação da corrida de carros.

$\mathrm{Na}$ década de 70, E. T. Vermeule publicou um trabalho abrangente sobre a arte e estética do mobiliário dos túmulos em poço de Micenas (Vermeule, 1975). Contudo, concentrou-se mais no aspecto da origem desse tipo iconográfico, que não apresentava precedentes nem sucessores no quadro do continente grego. Fechou definitivamente a questão sobre a origem micênica tanto do estilo como da temática.

Contudo, na década de 80 , o estudo da iconografia do período dos túmulos em poço ganhou uma nova dimensão, iniciada por R. Laffineur, que expôs sua visão de uma imagética metafórica, quase mágica, na qual ocorre uma redução do poder para emblemas estáticos. Contrapõe a arte micênica à arte minóica diferenciando o conceitualismo e o caráter emblemático da primeira do naturalismo da segunda (Laffineur, 1983, p. 113). O que é realmente importante não é somente estabelecer o que seja minóico ou micênico, mas sim penetrar na significação real das categorias iconográficas presumidas e definir o que as diferencia fundamentalmente. As duas categorias apresentadas pelas estelas são 1) carros em movimento e 2) cenas de caça, que apresentam, por sua vez, em dois níveis: homens caçando leões e leões caçando outros animais. Estas duas categorias abrangem também a glíptica e a decoração das espadas e adagas provenientes dos túmulos dos Círculos Tumulares A e B (figuras nº 16,17 e 18).

Se observarmos apenas a iconografia das estelas, poderíamos concluir simplesmente que os micênios eram um povo guerreiro. Idéia que seria reiterada pela grande quantidade de armamento encontrada entre o mobiliário funerário. Contudo, a riqueza desse mobiliário, assim como a ausência total de fortificações, na acrópole de Micenas, no período dos túmulos em poço, demonstra uma situação de ausência de conflito, mesmo que iminente. Descartada a idéia de guerra e de que as imagens das estelas refletiriam narrativas dos feitos guerreiros dos ocupantes 
dos túmulos, poder-se-ia pensar numa narrativa de corrida de carros ou mesmo caça. Ora, nas imagens onde aparece o carro não aparecem animais, com exceção da estela 1 de Heurtley, mas ali observamos o desenvolvimento de duas cenas diferentes. Como sugeriu G. E. Mylonas (Mylonas, 1951, nota 17), tais imagens poderiam muito bem refletir um momento numa corrida de carros. Entretanto, por que o corredor estaria portando uma arma ofensiva como uma espada ou adaga? Só podemos concluir então que tais imagens não são narrativas, não contam um momento específico da vida do morto, muito menos narram sua morte: muito autores já são unânimes quanto a esta questão9.

Creio que a iconografia das estelas reflete um momento de afirmação durante o processo de estratificação social que ocorria, nesse momento, no continente grego ${ }^{10}$. Assim, o desenvolvimento de um repertório iconográfico que evidenciasse as qualidades guerreiras e a força individual seria bem lógico, compatível com a situação de viva competição que deveria prevalecer entre os indivíduos num momento de formação de estruturas de poder.

Assim, temos que tentar entender o código simbólico desenvolvido pelos micênios para tornar público e permanente, já que a estela funerária é um marco imóvel e visível, o caráter de excelência dessa elite governante sepultada em tais túmulos. Além das imagens de "carros em movimento" temos as de "animal atacando" e, neste caso, sempre quem ataca é o leão. Este animal tem um papel destacado que permeou todo o desenvolvimento da cultura e ficou mais evidenciado em Micenas (Younger, 1978). Nas estelas do Círculo Tumular B, e deve ser ressaltado que são contemporâneas ou poucos anos anteriores às do Círculo Tumular $\mathrm{A}$, o esquema iconográfico é bem definido. Um touro é atacado por leões que, por sua vez, são atacados por homens. O touro é a presa, os leões são predadores, mas ambos são dominados por um predador superior: o caçador/guerreiro humano. $O$ significado dessa imagem nada mais é que sugerir uma hierarquia em cujo ápice está o caçador/guerreiro humano. Podemos perceber este esquema também na glíptica (Marinatos, 1990, p. 147). O leão é mostrado sempre como um adversário formidável que os humanos tentam matar. Esse esquema também é observado nos motivos decorativos dos armamentos encontrados nos túmulos. Percebe-se, então, uma identificação do caçador/guerreiro humano com o seu adversário, no caso, o leão. Somente uma mensagem fica clara nessa hierarquia de poder em que natureza e cultura desempenham papéis pouco definidos: não é o "senhor dos animais", mas o "senhor dos homens", que querem refletir (Marinatos, 1990, p. 147).

Da mesma forma, o outro grupo iconográfico, representado pelo carro, um objeto ao qual pouquíssimos, senão somente o próprio governante, teriam acesso, só pela sua presença, seja em caça, corrida ou guerra, demonstra o alto status do indivíduo sepultado (Crouwel, 1981). Restanos ainda o esquema iconográfico da estela 1 no qual, ao mesmo tempo, encontramos uma cena com o carro em movimento, como nas estelas 4 e 5, e um leão perseguindo uma presa. Estilisticamente esta é a estela mais refinada; o tratamento dado às espirais é mais delicado e é diferente dos padrões presentes nas outras estelas, limitados a espirais concatenadas. E mais: sob as patas do cavalo, após décadas de discussão, observou-se um guerreiro caído sob um escudo em forma de 8 . Aqui a colocação das duas imagens num mesmo registro mostra uma explicitação do simbolismo: como o leão alcança sua presa, o homem subjuga seus inimigos.

Portanto, as imagens que enfatizam o poder individual do guerreiro refletem o local do indivíduo deposto na hierarquia social. Parece que temos de fato dois repertórios iconográficos diferentes relacionados a expressões de qualidades socio-políticas e de status, os quais parecem ter seguido o desenvolvimento cronológico da cultura. A representação do carro e do leão da transição do Heládico Médio III para o Heládico Recente I (c. 16501500 a.C.) dará lugar aos grupos antitéticos e hieráticos de leões e grifos do Heládico Recente IIIA:1 em diante, como o relevo da Porta dos Leões em Micenas e muitos selos e anéis de sinete (figura ${ }^{\circ} 18$ ). $O$ primeiro repertório exalta as qualidades individuais dos membros de uma elite. Já o segundo utiliza o leão, 
o grifo e outros animais como guardiães da autoridade do governante que a está exercendo. Isto parece corresponder à evolução social e política que foi descrita por C. B. Mee e W. G. Cavanagh a partir das evidências dos túmulos micênicos e seu mobiliário (Mee \& Cavanagh, 1984, p. 62).

Tão logo são desenvolvidas autoridades centralizadas nos diferentes distritos da Grécia micênica e uma certa estabilidade política é alcançada, a necessidade de qualidades individuais é substituída pela necessidade de proteger e preservar a nova autoridade estabelecida. Tal afirmação de poder e autoridade certamente implica na emergência de grandes estados/distritos, bem como a construção de palácios (Wright, 1987) e o desenvolvimento de uma iconografia monumentalizada como a Porta dos Leões em Micenas, já citada, e o afresco dos grifos no palácio de Pilos e no palácio de Cnossos.

\section{Notas}

1. Para uma definição da tipologia dos túmulos em poço dos Círculos Tumulares $\mathrm{A}$ e $\mathrm{B}$ de Micenas cf. Torralvo, A. C., 1993, p. 21-56 e p. 112.

2. Estelas $=$ stelai , termo grego que define um marco funerário, lápide.

3. Sobre a nomenclatura dos túmulos, cf. Torralvo, A. C., 1993, nota 2.

4. A numeração utilizada neste estudo, para as estelas do Círculo Tumular A, é a mesma encontrada em Heurtley, 1921-3. As estelas do Círculo Tumular B, cuja descoberta é posterior, serão designadas pelas letras gregas que identificam os túmulos sobre os quais foram encontradas, ou seja, A e $\Gamma$.

5. Nos últimos 110 anos esse animal já foi descrito como cavalo, ibex, cabra e corça. Cf. N. Marinatos, 1988, p. 147.

6. O Cicládico Médio III corresponde ao final da Idade do Bronze Médio nas ilhas Cíclades, aproximadamente o mesmo período dos túmulos em poço dos Círculos Tumulares de Micenas.

7. A adição das estelas $\mathrm{A}$ e $\mathrm{G}$ na Classificação de W. A. Heurtley é de minha responsabilidade já que, quando foi feita, o Círculo Tumular B ainda não havia sido descoberto. A única referência que confirma minha opção é Hooker, 1976.

8. Vaso em bronze do túmulo $\mathrm{V}$, bojo do vaso decorado com o mesmo padrão de espirais concatenadas em Evans, 1929, figuras $15 b$ e 35, em que compara os mesmos motivos utilizados nos túmulos de Micenas, em Creta e no Egito.

9. Xenaki-Sakellariou, 1985, p. 308; Niemeier, 1992, p. 97-104 e Laffineur, 1990, p. 117-160.

10. Graziadio, 1991, p. 400-403 e Torralvo, 1993, nota 2 e cf. Conclusões.

\section{Referências Bibliográficas}

ÅKERSTÖM, Å. Cultic installations in Mycenaean rooms and tombs. In: FRENCH, E. \& WARDLE, K. A. (eds.) Problems in Greek Prehistory (Papers presented at the Centenary Conference of the British School of Archaeology of Athens, Manchester april 1986) Bristol: Bristol Classical Press, 1988. p. 201-210.

CROUWEL, J. H. Chariots in Bronze Age Greece (Allard Pierson Series, vol. 3). Amsterdam: Allard Pierson, 1981. 
EVANS, A. The Shaft Graves \& Bee-hive Tombs at Mycenae, London, 1929.

GATES, C. Rethinking the building history of Grave Circle A at Mycenae. In: American Journal of Archeology, n. 89, p. 263-274, 1985.

GRAZIADIO, G. The chronology of the graves of Circle B at Mycenae: a new hipothesis. In: American Journal of Archaeology, n. 92, p. 343-372, 1988.

GRAZIADIO, G. The process of social stratification at Mycenae in the shaft grave period: a comparative examination of the evidence. In: American Journal of Archaeology, n. 95. p. 403$440,1991$.

HEURTLEY, W. A. The grave stelai. In: Journal of the British School of Athens, n. 25, p. 126-146, 1921-3.

HOOKER, J. T. Mycenaean Greece. Londres: Routledge \& Kegan Paul, 1976.

KILIAN, K. Mycenaeans up to date, trends and changes in recent research. In: FRENCH, E. \& WARDLE, K. A. (eds.) Problems in Greek Prehistory (Papers presented at the Centenary Conference of the British School of Archaeology of Athens, Manchester april 1986). Bristol: Bristol Classical Press, 1988, p. 115-152.

KILIAN-DIRLMEIER, I. Jewellery in Mycenaean and Minoan 'Warrior Graves'. In: FRENCH, E. \& WARDLE, K. A. (eds.) Problems in Greek Prehistory (Papers presented at the Centenary Conference of the British School of Archaeology of Athens, Manchester april 1986). Bristol: Bristol Classical Press, 1988; p. 161-172.

LAFFINEUR, R. Les vases en métal précieux à l'époque mycénienne (Studies in Mediterranean Archaeology, pocket-book 4). Goteborg: Paul Astrom, 1977.

LAFFINEUR, R. Early Mycenaean art: some evidence from the West House in Thera. In: Bulletin of the Institute of Classical Studies, v. 30, p. 111-122, 1983.

LAFFINEUR, R. The iconografy of Mycenaean seals and the status of their owners. In: Aegaeum 6(1990) p. 117-160.

LAFFINEUR, R. Grave Circle A at Mycenae: further reflections on its history. In: HÄGG, R. \& NORDQUIST, G. C. (eds.) Celebrations of Death and Divinity in the Bronze Age Argolid (Proceedings of the $6^{\text {th }}$ International Symposium at the Swedish Institute at Athens, 11-13 june 1988). Stokholm: Paul Åström Förlag, 1990, p. 201-206.

MARCUS, J. The iconography of power among the classic mayas. In: World Archaeology, v. 6, p. 83-94, 1974.

MARINATOS, N. Celebrations of death and the symbolism of the lion. In: HÄGG, R. \& NORDQUIST, G. C. (eds.) Celebrations of Death and Divinity in the Bronze Age Argolid (Proceedings of the $6^{\text {th }}$ International Symposium at the Swedish Institute at Athens, 11-13 june 1988). Stokholm: Paul Åström Förlag, 1990, p. 143-148.

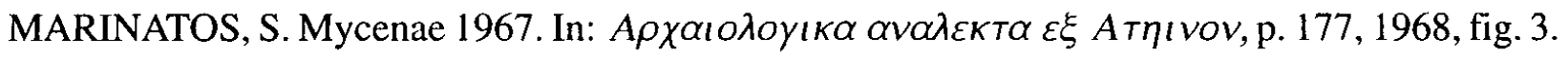

MORRIS, C. In pursuit of the white tusked boar: aspects of hunting in Mycenaean society. In:

HÄGG, R. \& NORDQUIST, G. C. (eds.) Celebrations of Death and Divinity in the Bronze Age Argolid (Proceedings of the $6^{\text {th }}$ International Symposium at the Swedish Institute at Athens, 11-13 june 1988). Stokholm: Paul Åström Förlag, 1990, p. 149-156.

MYLONAS, G. E. Grave Circle B of Mycenae (Studies in Mediterranean Archaeology 7). Lund: Carl Bloms, 1964.

MYLONAS, G. E. The figured Mycenaean stelai. In: American Journal of Archaeology, v. 55, p. 134-147, 1951.

NIEMEIER, W.-D. Iconography and context: the Thera frescoes. In: LAFFINEUR, R \& CROWLEY, J. L. (eds.) EIKON. Aegean Bronze Age iconography: shaping a methodology (Proceedings of the $4^{\text {th }}$ International Aegean Conference/4éme Rencontre Égéenne Internationale University of Tasmania, Hobart, Australia - 6-9 april 1992). Liège: Université de Liège, 1992 ( = Aegaeum 
8 ).p. 97-104.

OZANNE, I. Les Mycéniens. Paris: Armand Colin, 1992.

PEARSON, M. P. The powerful dead: archaeological relationships between the living and the dead. In: Cambridge Archaeological Journal, v. 3, p. 203-229, 1993.

PELON, O. Tholi, tumuli et cércles funéraires. Paris: De Boccard, 1976.

PELON, O. Origine de la culture de tombes à fosse en Grèce continentale - données archicteturales et ritualles. In: Études Indo-Européennes. p. 13-29, 1985.

POURSAT, J.-C. Les ivoires mycéniens. Paris: De Boccard, 1977.

RANDSBORG, K. The archaeology of the visual: burials past and prestent. In: Dialoghi di Archeologia, n. 7, p. 85-96, 1989.

SAUNDERS, N. J. Predators of culture: jaguar symbolism and Mesoamerican elites. In: World Archaeology, n. 26, p. 49-59, 1991.

SCHLIEMANN, H. Mycenae: a narrative of researches and discoveries at Mycenae and Tiryns. Salem: Ayer Co., 1880.

SCHNAPP, A. La raison du chasseur. In: Dialoghi di Archeologia. n. 8, p. 49-59, 1990.

TORRALVO, A. C. As dimensões sociais dos costumes funerários entre os micênios, dissertação de mestrado, Departamento de Antropologia, 1993.

VERMEULE, E. T. The art of the shaft graves at Mycenae (Lectures in memory of Louis Taft Sample). Cincinnati: University of Cincinnati, 1975.

WRIGHT, J. C. Death and power at Mycenae, changing symbols in mortuary practices. In: LAFFINEUR, R. (ed.) Thanatos. Les coutumes funéraires en Égée à l'Âge du Bronze (Actes du Colloque de Liège, 21-23 avril 1986). Liège: Université de Liège, 1987 (= Aegaeum 1). p. 171-184.

XENAKI-SAKELLARIOU, A. Identité minoenne et identité myceniénne. In: L'iconographie minoenne (BCH Suppl. 11). Paris: De Boccard, 1985, p.308 e ss.

YOUNGER, J. G. The Mycenae-Vaphio lion group. In: American Journal of Archaeology, v. 82, p. 285-299, 1978.

YOUNGER, J. G. Aegean seals of the Late Bronze Age: masters and workshops. In: Kadmos, n. 23, p. 38-64, 1984.

TORRALVO, A. C. L'iconographie des stelai funéraires des Cércles A et B de Mycénes, Classica, São Paulo, 7/8: 33-51, 1994/1995.

RÉSUMÉ: Cet article se compose de deux parties: la première est constituée d'un catalogue des stèles funéraires avec décor en relief, provenant des Cercles Funéraires $A$ et $B$ de Mycènes; la deuxième partie propose une analyse où sont considerées les positions antérieures à la découverte du Cercle Funéraire $B$. À ces positions j'oppose une autre plus récent qui voit les images des stèles comme des représentations symboliques liées à un stade évolutif determiné de la société mycénienne, laquelle passe, à cette époque-là, par un procès de consolidation des élites et d'établissement des relations de pouvoir, plus précisément la naissance de la société palatiale mycénienne.

MOTS CLÉS: Cèrcles Funéraires, estèles, Mycènes, pouvoir, symbologie, société. 


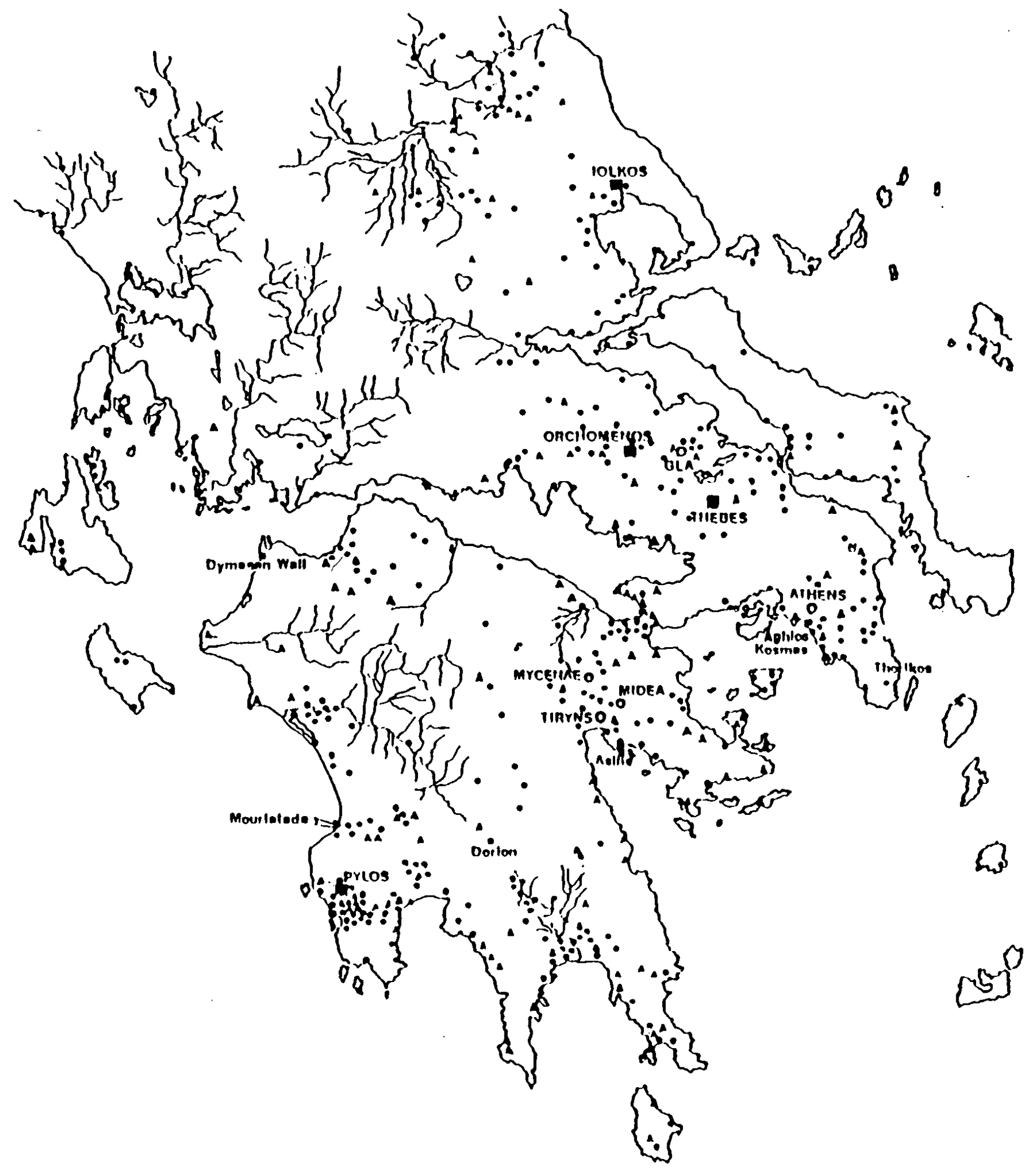

Figura 1: Grécia durante o século XIII a. C. 


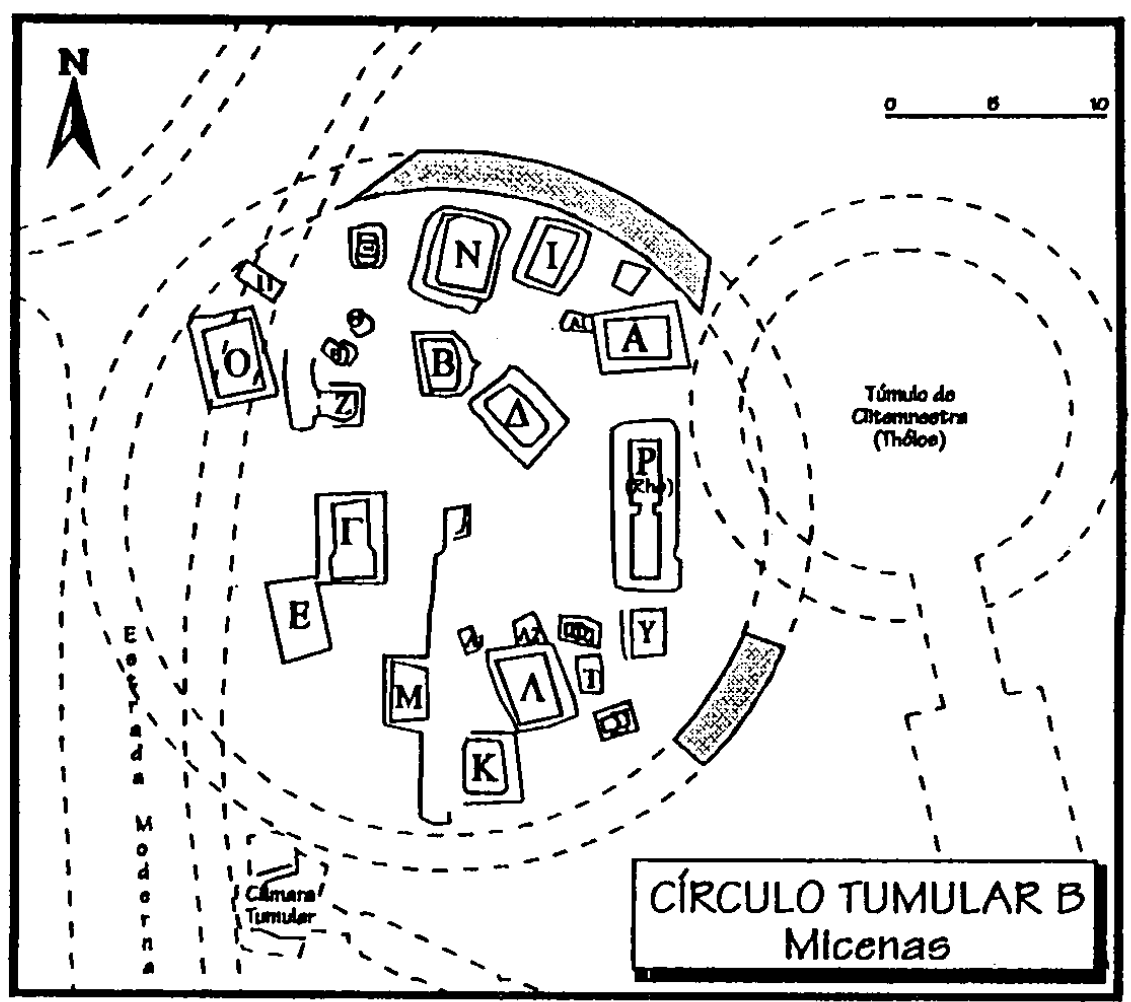

Figura 2: Acima: Círculo Tumular B com seus 26 túmulos designados por letras do alfabeto grego. Abaixo: Círculo Tumular A e seus seis túmulos designados por números romanos.

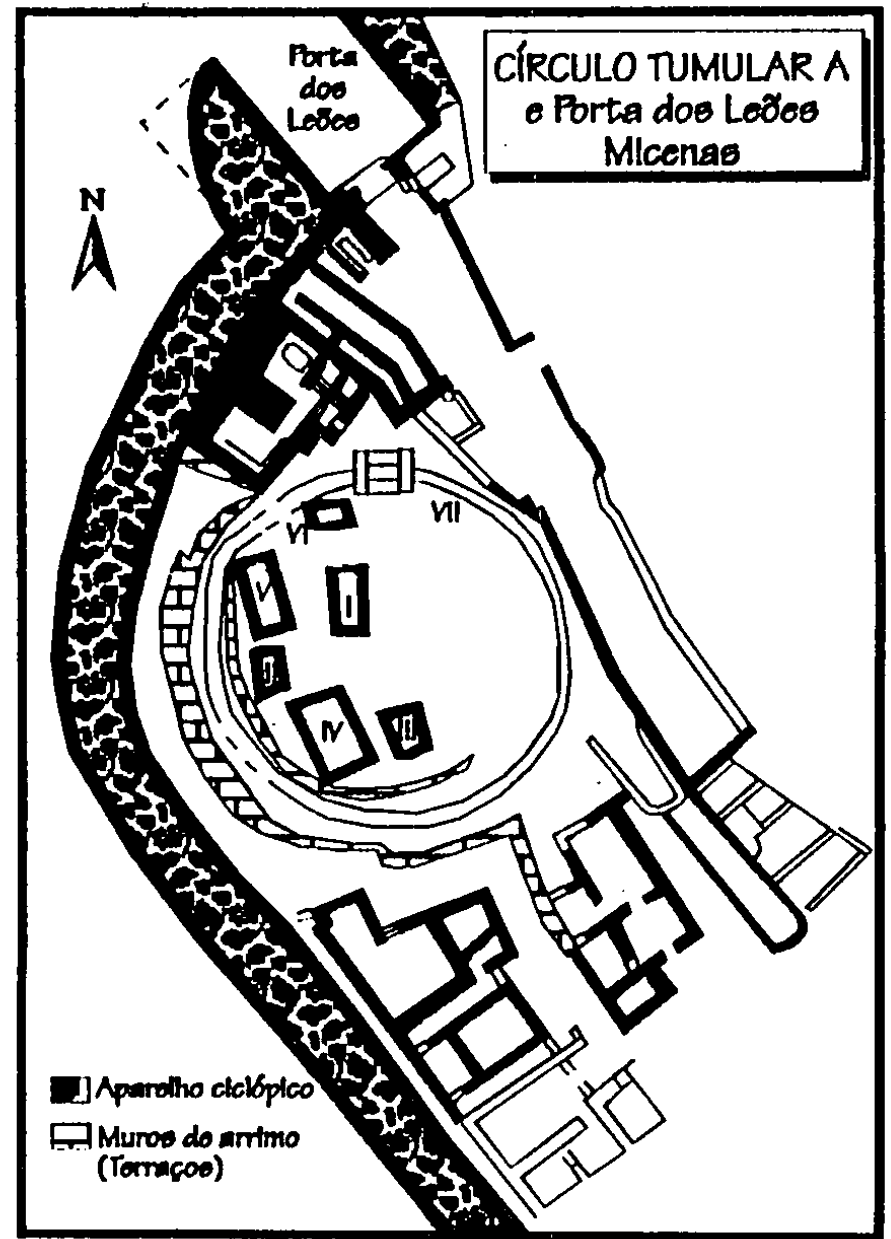



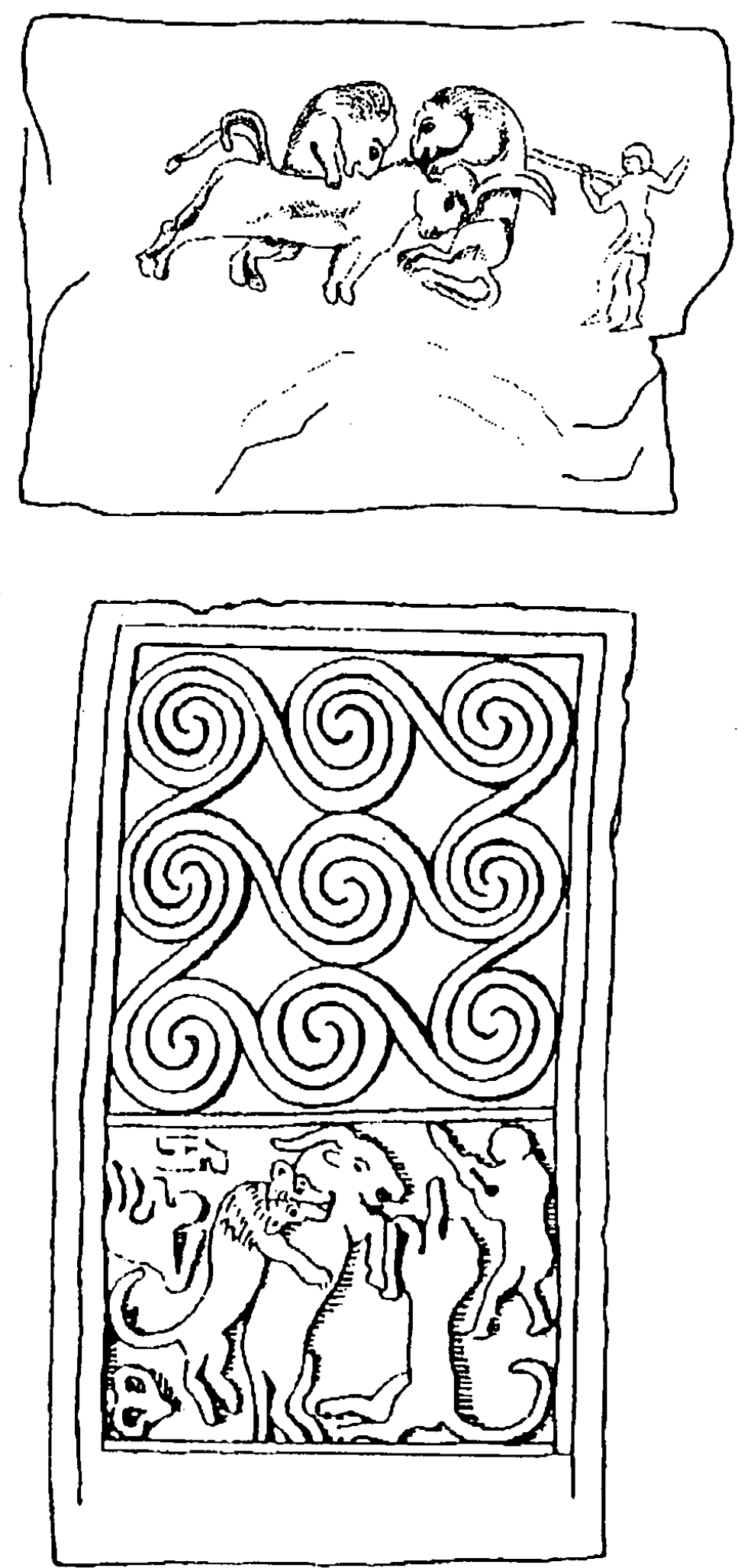

Figura 3: Acima: representação contida na estela A do Círculo Tumular B, segundo G. E. Mylonas. Abaixo: Restauração conjectural da estela $G$ do Círculo Tumular B, segundo $S$. Marinatos (a partir de Marinatos, 1990, p.144-5) 

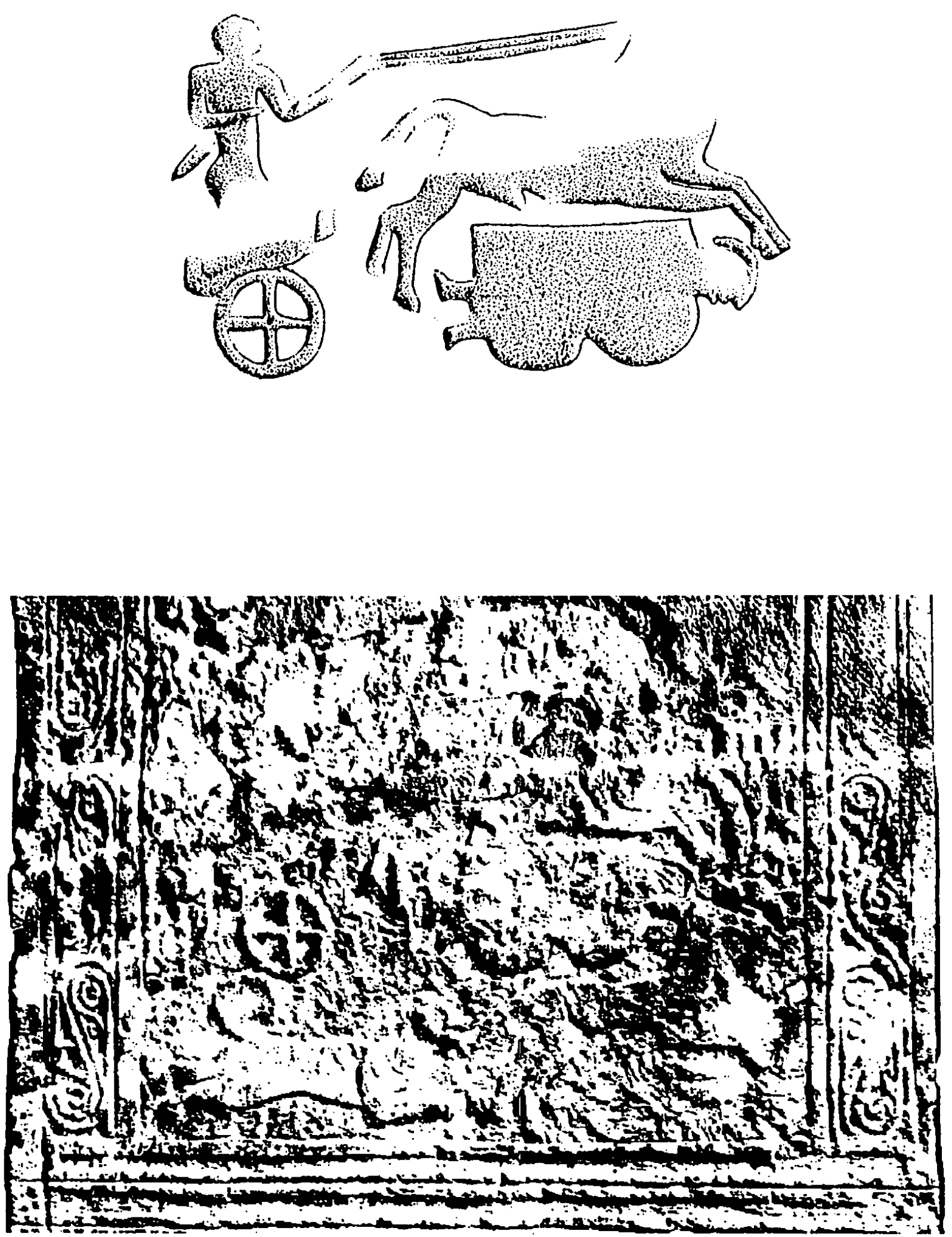

Figura 4: Estela 1 (a partir de Heurtley,1921-23) 


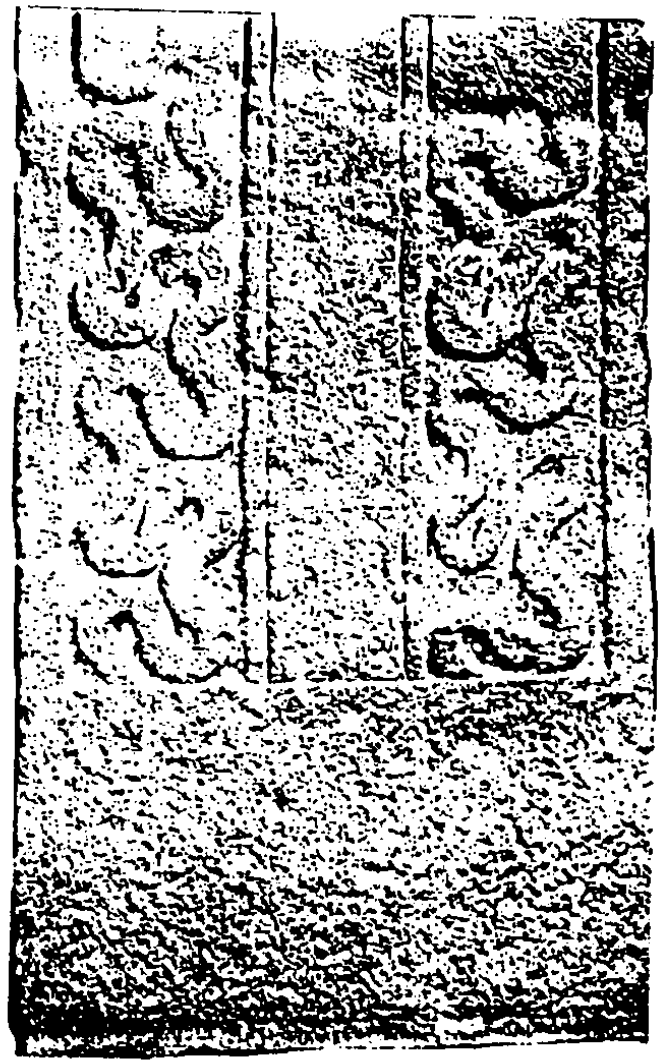

Figura 5: Estela 2 (a partir de Heurtley, 1921-23)

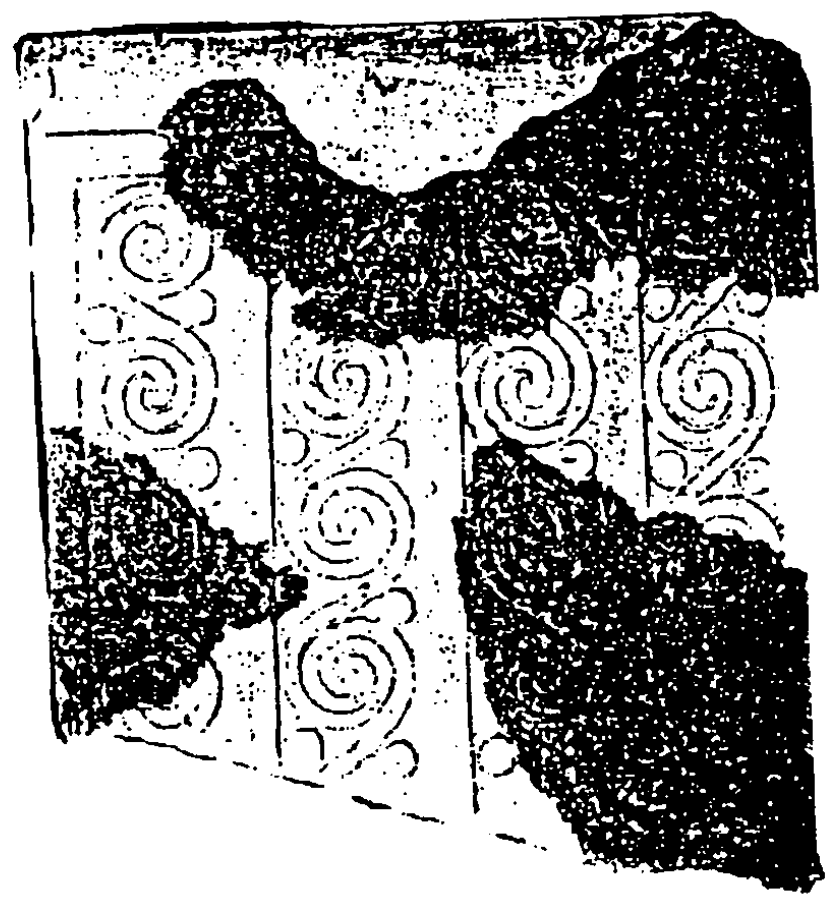

Figura 6: Estela 3 (a partir de Heurtley, 1921-23) 

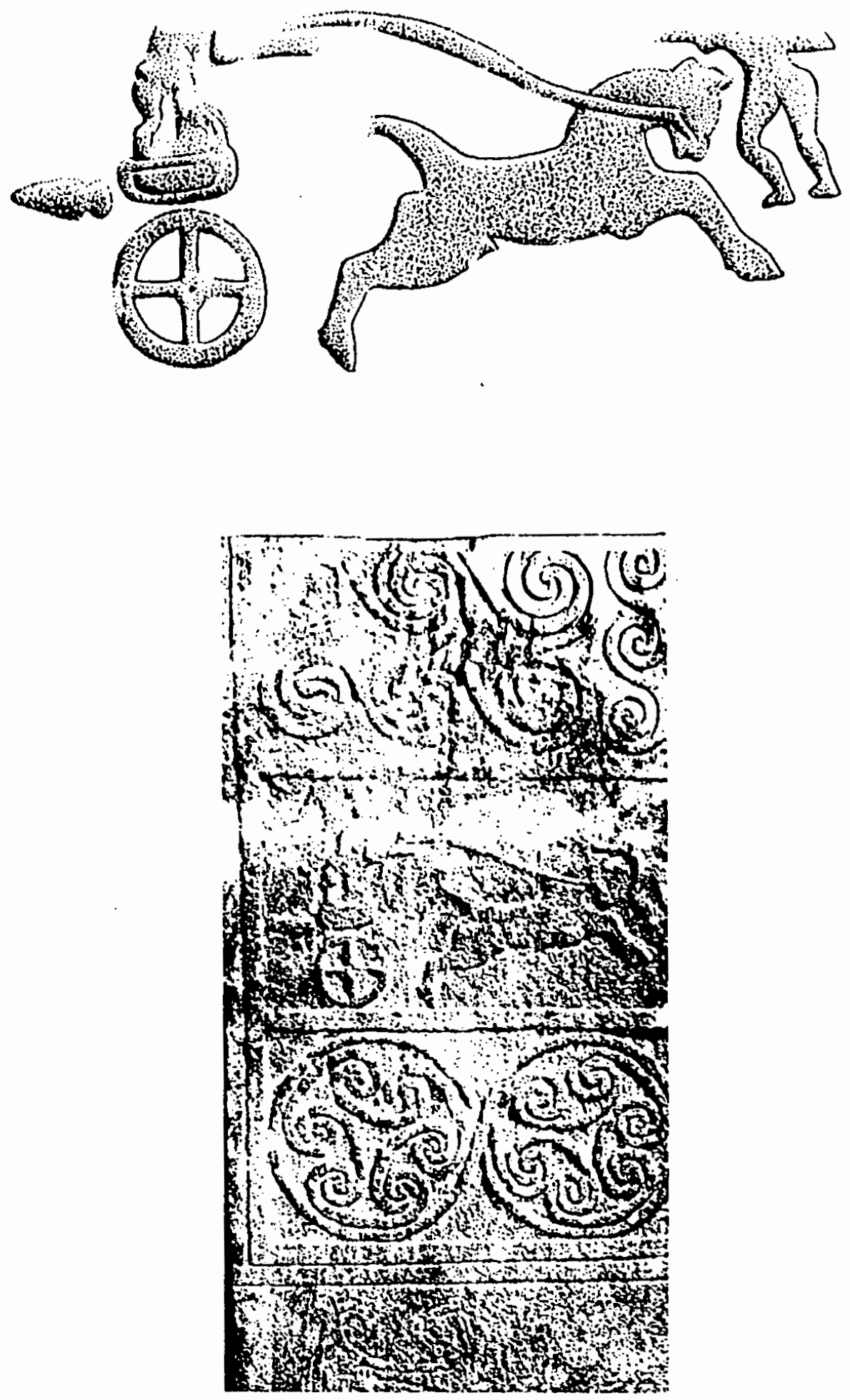

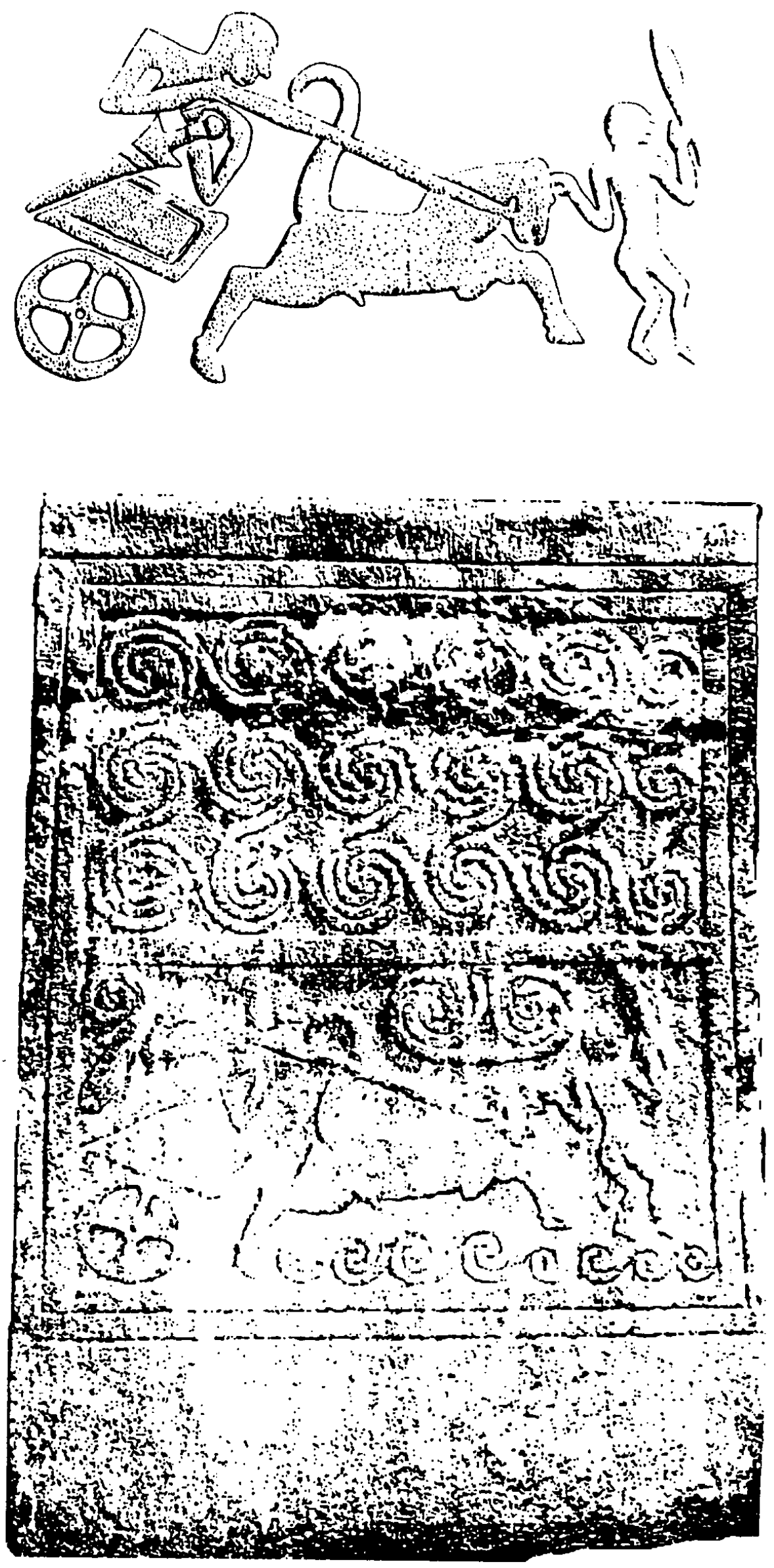

Figura 8: Estela 5 (a partir de Heurtley, 1921-23) 


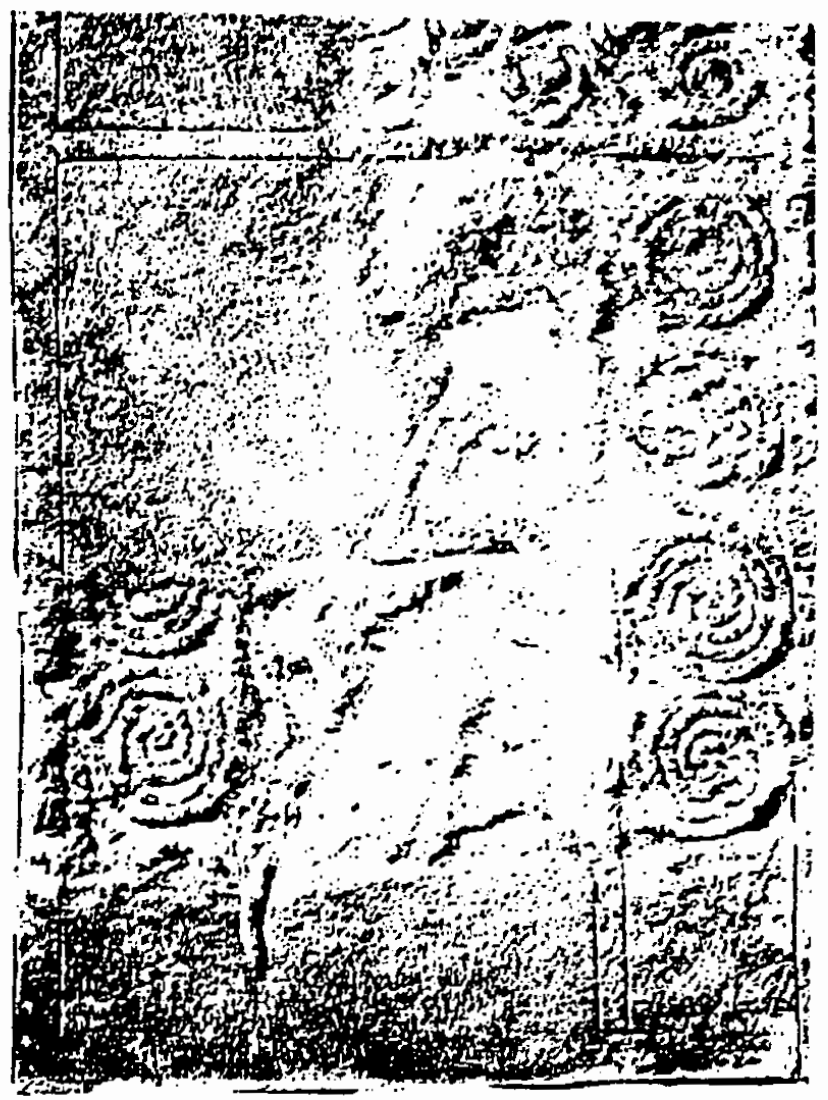

Figura 9: Estela 6 (a partir de Heurtley, 1921-23)

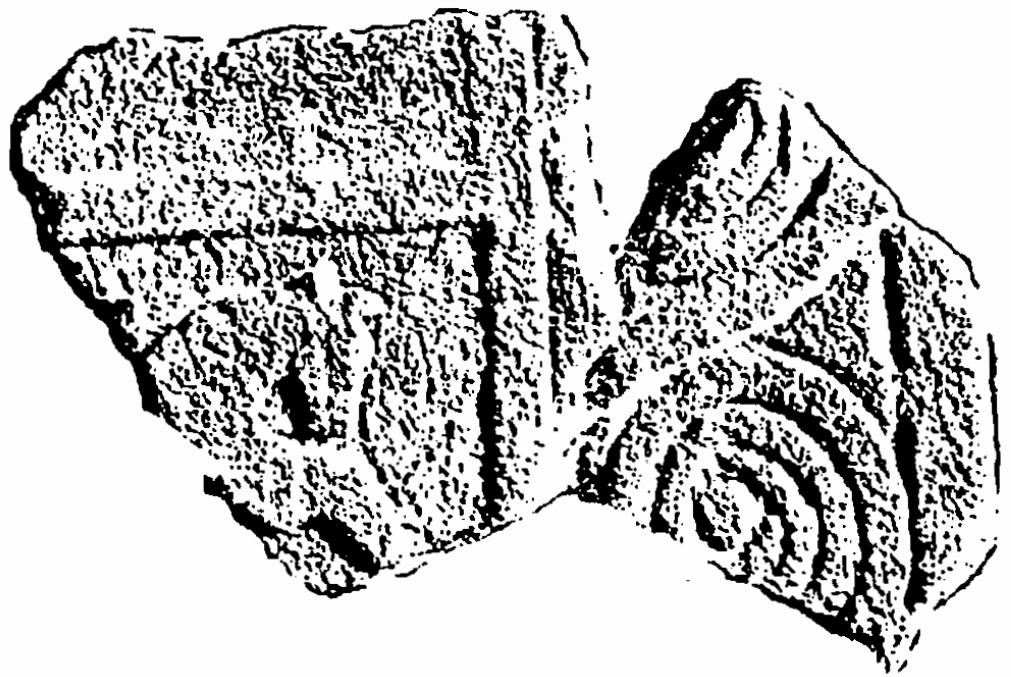

Figura 10: Estela 7 (a partir de Heurtley, 1921-23) 


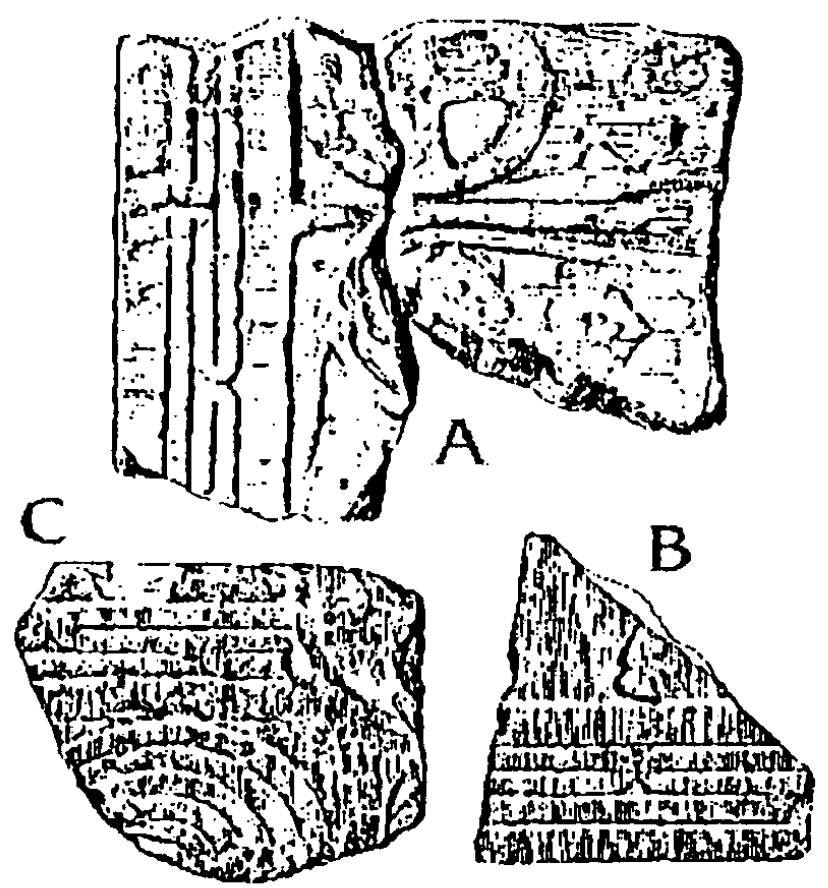

Figura 11: Estela 8 (a partir de Heurtley, 1921-23)

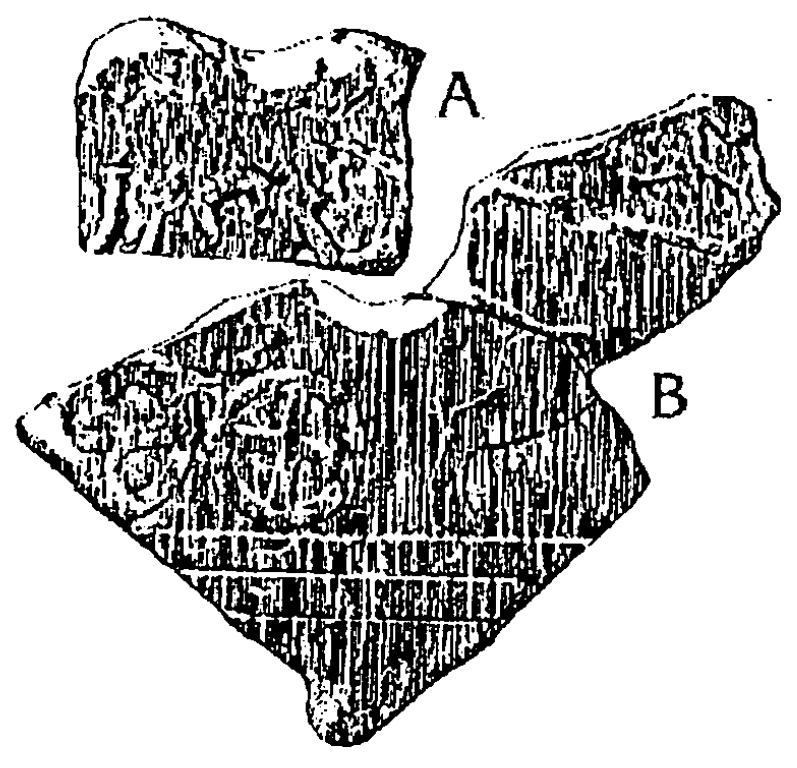

Figura 12: Estela 9 (a partir de Heurtley, 1921-23)
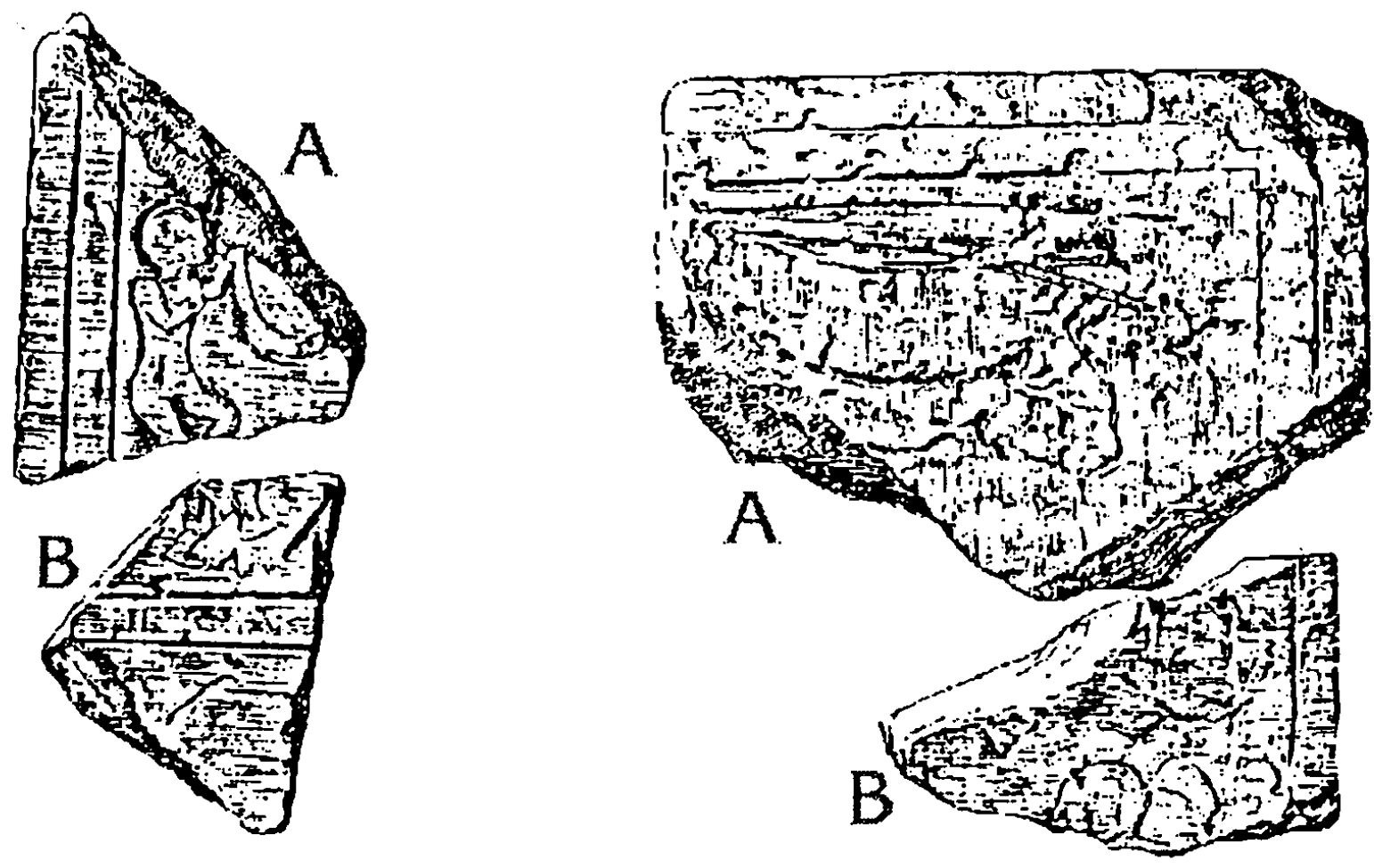

Figura 13: Estela 10 (a partir de Heurtley, 1921-23) Figura 14: Estela 11 (a partir de Heurtley, 1921-23) 

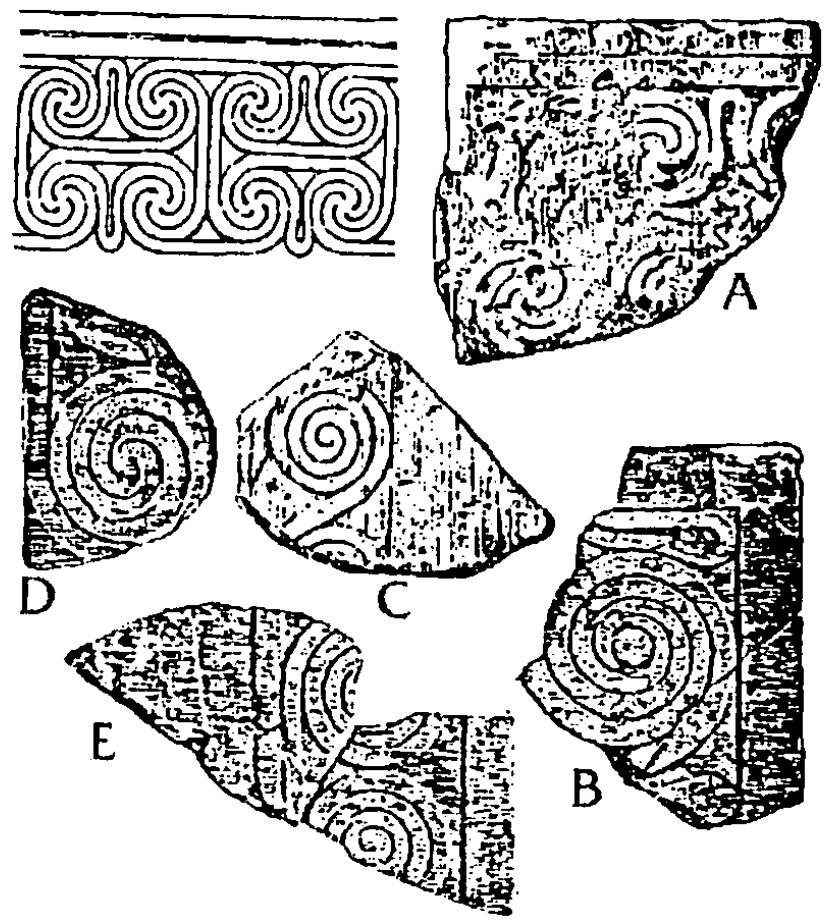

Figura 15: Estela 12 (a partir de Heurtley, 1921-23)
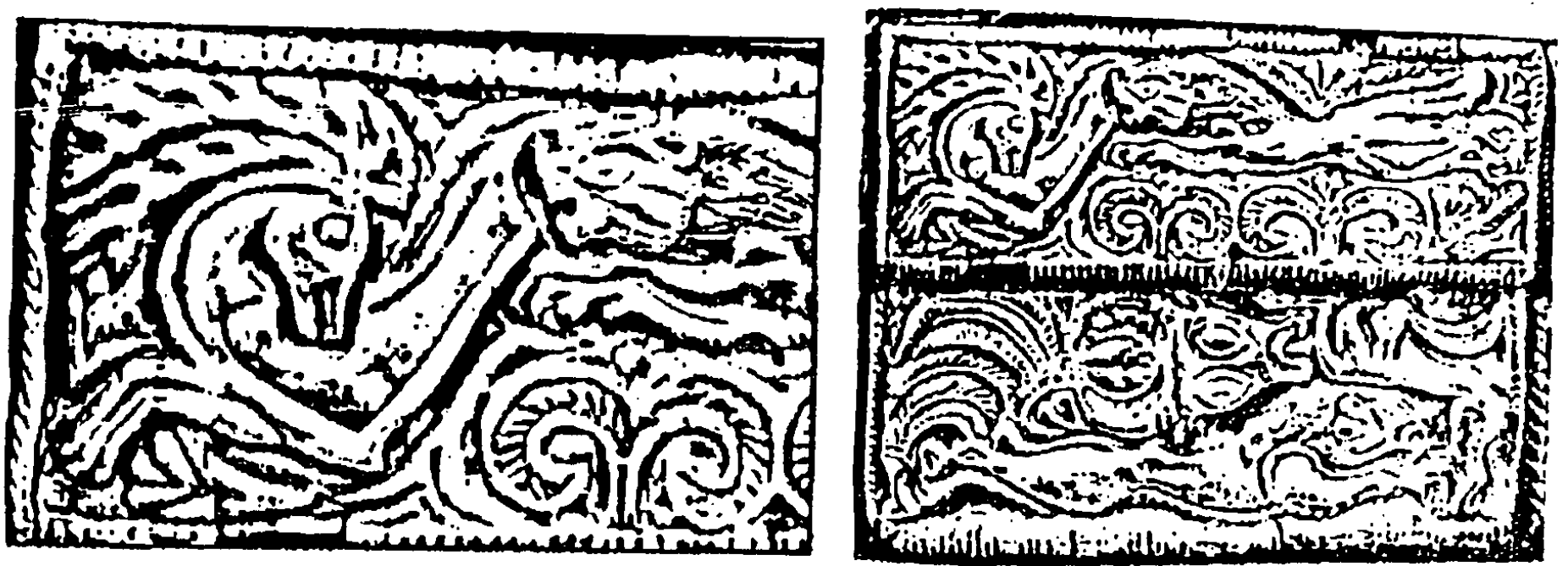

Figura 16: Revestimento em folhas de ouro de uma pixide, decorado emrepoussé, com cena de ataque de leões (proveniente do Círculo Tumular A). 

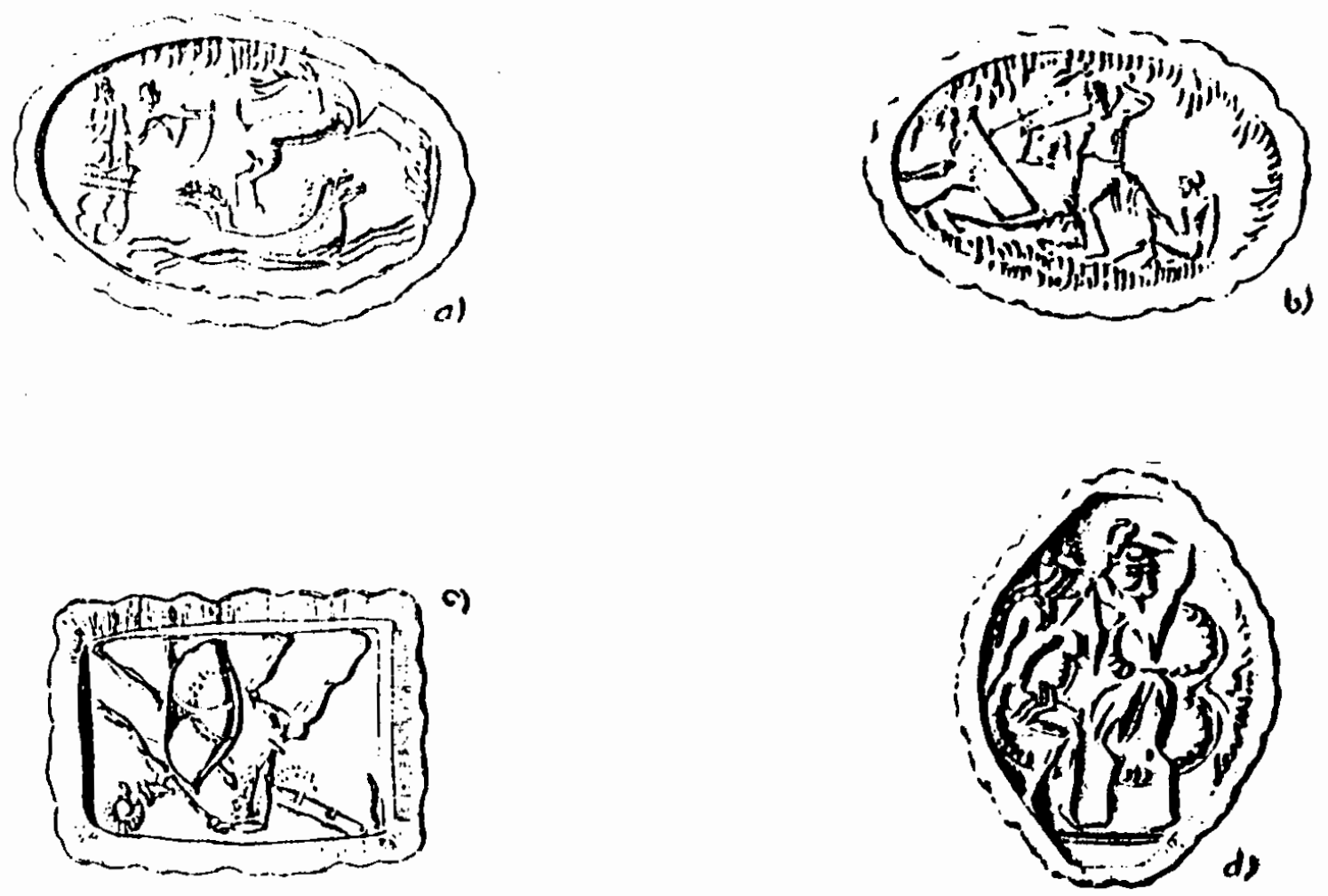

Figura 17: a partir de Sakellariou, A. Die Minoischen und Mykenischen Siegel des Nationalmuseums in Athens, Berlim, Verlag, 1964. - a) Anel de sinete em ouro ( $n^{\circ}$ de registro 240) proveniente do túmulo $I V-b)$ Anel de sinete em ouro ( $n^{\circ}$ de registro 241 ) proveniente do túmulo $\left.I V-c\right)$ Selo em ouro $\left(n^{\circ}\right.$ de registro 35$)$ proveniente do túmulo $\left.I I I-d\right)$ Selo em ouro ( $n^{\circ}$ de registro 116$)$ proveniente do túmulo $I I I$.

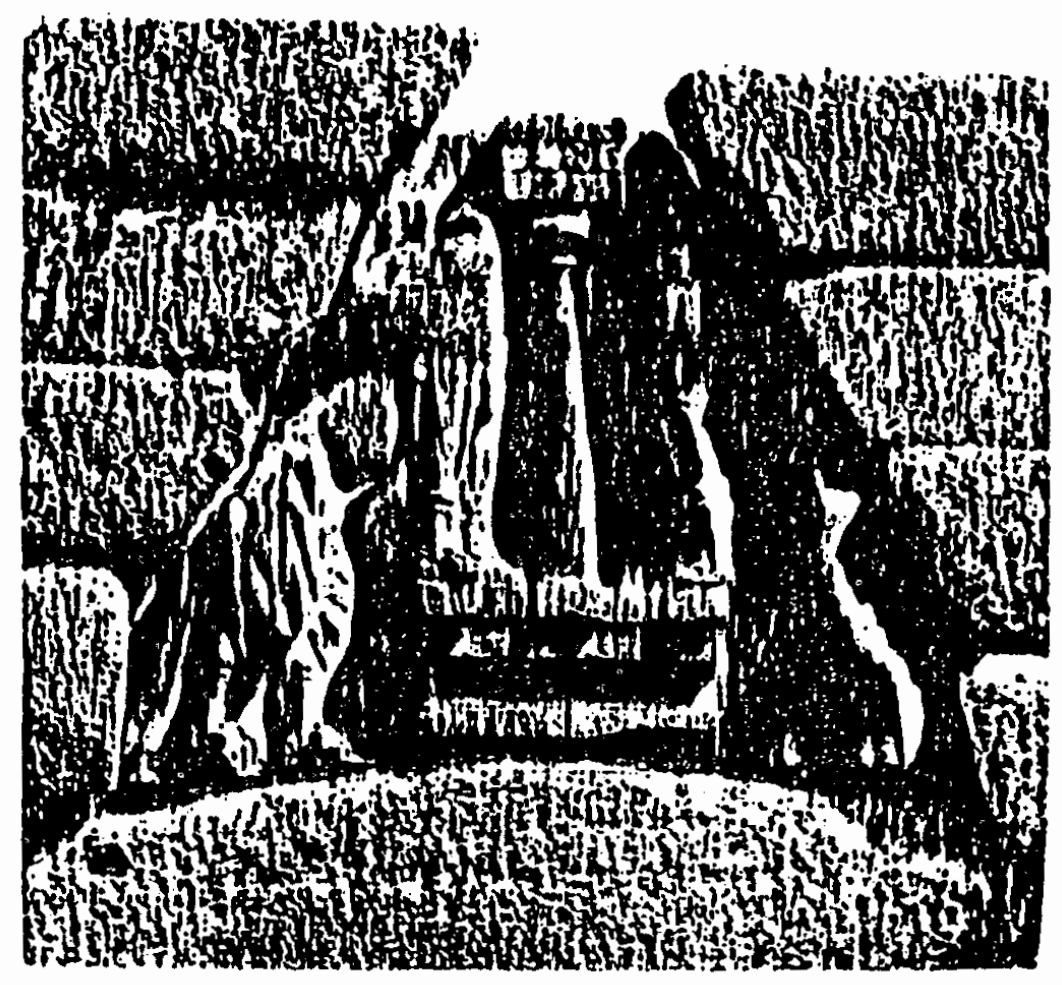

Figura 19: Porta dos Leões, em Micenas (a partir de Ozanne, 1990) 